\title{
Analysis of Pedagogic Competence and Professional Competence of Physics Teachers
}

\author{
$1^{\text {st }}$ Andi Reski* \\ Department of Physics Education \\ Universitas Musamus \\ Merauke, Indonesia \\ andireski_fkip@unmus.ac.id
}

\author{
$2^{\text {st }}$ Supriyadi \\ Department of Physics Education \\ Universitas Musamus \\ Merauke, Indonesia \\ supriyadi_fkip@unmus.ac.id
}

\author{
$3^{\text {st }}$ Martha Loupatty \\ Department of Physics Education \\ Universitas Musamus \\ Merauke, Indonesia \\ loupatty@unmus.ac.id
}

\begin{abstract}
Research has been conducted to describe the pedagogical competence and professional competence of physics teachers. The population in this study were all physics teachers in Merauke District. Furthermore, determining the sample using a purposive sampling technique because not all members of the population can be used as research samples. A total of 11 physics teachers were sampled in this study. The research method used was a survey method with data collection techniques using instruments in the form of questionnaire sheets. The questionnaire used contained 30 statement items using a Likert scale. The data obtained is quantitative data which is then analyzed using descriptive statistics. The results showed that the pedagogical competence and professional competence of physics teachers were in the medium category with percentages of $57.4 \%$ and $53.3 \%$, respectively. In this study, the percentage of pedagogic competence and professional competence of physics teachers is strongly influenced by the ability of teachers to integrate pedagogic knowledge and content knowledge with technological knowledge. The results of this study indicate that physics teachers who teach in Merauke District have not been able to carry out physics learning based on information and communication technology.
\end{abstract}

Keywords-competence, pedagogic, professional, physics teacher

\section{INTRODUCTION}

Teacher professionalism is one of the factors that influence the quality of education. This can be seen from the task of the teacher as a professional educator that is educating, teaching, guiding, directing, assessing, and evaluating students. Therefore, a teacher is a professional staff which implies that the teaching profession can only be done by someone who has competence.

Competence is an ability that must be possessed by someone who works as an educator (teacher and lecturer). Law Number 14 of 2005 explains that a teacher must have 4 kinds of competencies, namely professional, pedagogical, social and personal competencies [1]. Based on this law, the Government then developed a pattern to measure the level of professionalism of teachers by carrying out teacher competency tests (UKG). The UKG results are then used as a requirement for teachers to obtain educator certificates and the title of a professional teacher.
This requirement applies to all community members who work as teachers in Indonesia, including in Merauke Regency in the southern part of Papua. As for the data obtained from the regional educator's balance sheet, it shows that in 2019 the average teacher competency test results (SD /SMP/SMA/SMK) in Merauke Regency were $53.91 \%$ and were the second-highest UKG scores in Papua Province with a competency score pedagogic $51.70 \%$ and the value of professional competence $54.85 \%$. From this data, information is obtained that the quality of education in the Merauke Regency is still in the medium category.

One way to support the Government's program in improving the quality of education delivery, especially at the secondary education level, it is necessary to measure teacher quality. The quality of a teacher can be measured through his competence. Teacher competence can be seen from the knowledge held in accordance with their respective fields of science. According to Mishra and Koehler, there is 3 knowledge that must be mastered by the teacher namely pedagogic knowledge, content knowledge, and technological knowledge. All three of this knowledge need to be mastered by the teacher to be able to carry out effective, efficient, and conducive learning. Especially for abstract subjects such as physics, the mastery of knowledge is very helpful for students in understanding the concepts of physics to solve concrete problems. Therefore, professionals of educators can be seen from the teaching abilities of students [2].

Pedagogic knowledge is the teacher's knowledge of various methods and strategies in implementing learning to support the learning process of students (Koehler, et All). According to the Republic of Indonesia government regulation No. 19 of 2005 explains that teacher pedagogical competence is the ability of teachers to manage learning which consists of an understanding of students, curriculum/syllabus development, learning design, learning implementation, evaluation of learning outcomes, and student development to actualize various potentials [3]. Collaboration between pedagogic knowledge and technology knowledge is related to teacher knowledge in mastering a variety of technologies for use in teaching so that the use of technology can change the teacher's method of teaching [4].

Content knowledge is knowledge about concepts, theories, ideas, frameworks, knowledge of proof as well as practices and approaches for developing knowledge [5]. Content knowledge is a translation of a teacher's professional 
competence. This is explained in the Republic of Indonesia government regulation No. 19 of 2005 that professional competence is the ability in mastering broad and deep learning material related to concepts, theories, and methods [3]. Furthermore, the combination of content knowledge and technology knowledge will produce knowledge about the reciprocal relationship between technology and content [6]. The combination of this two knowledge is also commonly referred to as technological content knowledge is a form of knowledge about the integration of technology in the learning process including knowledge about the selection of technology by the content to be taught [7]. The use of technology can make it easier to understand concepts in content or learning material [4]. Therefore, the ability to learn and adapt to technology is very important in supporting the improvement of teacher competency. Based on the explanation above, it is considered important to conduct this research to obtain data and an overview of the level of competency possessed by physics teachers, especially pedagogic and professional competencies.

\section{RESEARCH METHODS}

This research is a quantitative descriptive study with a survey method. The survey method used is a descriptive survey method that aims to describe the pedagogic and professional competencies of physics teachers in the Merauke District. The population in this study were physics teachers (SMA/SMK/MA) in the Merauke District. Furthermore, the research sample was determined using a purposive sampling technique because not all members of the population could be sampled. A total of 11 physics teachers from secondary schools (SMA/SMK/MA) were sampled in this study.

There are 4 stages carried out in this study, namely: 1) making statement items, 2) collecting data, 3) analyzing data, 4) concluding. The research method used was a survey method with data collection techniques using instruments in the form of questionnaire sheets. The questionnaire contained 30 items of statements based on 3 components of knowledge introduced by Mishra and Koehler [4]. The three components of knowledge are pedagogic knowledge, content knowledge, and technological knowledge. The score assessment for the questionnaire uses a 5-point Likert scale. The 5-point Likert Scale was taken as a benchmark on all statement items in the questionnaire. So the alternative answers on the measurement scale consist of 5 choice attitude scales. The 5 choice attitude scales used in this study are SB means very able, $B$ means able, CB means sufficient can, TB means cannot, and STB means very cannot. According to Riduwan, each alternative answer on the Likert scale has a score like the following: $\mathrm{SB}=5, \mathrm{~B}=4, \mathrm{CB}=3$, $\mathrm{TB}=2$, dan STB $=1[8]$.

Furthermore, data collection was carried out by distributing the questionnaire to the physics teacher who became the research sample. Data obtained in the field were then analyzed using descriptive statistical analysis techniques. This analysis aims to describe the data collected as it is from each component of pedagogic and professional competence. Tabulation of data in the form of the total score of each statement item and the percentage of total scores for each competency component. The results of data analysis are presented in the form of a histogram as a form of data interpretation of each component. As for determining the criteria or score categories of each component, it is presented in 5 interval classes based on Riduan and Akdon's categorization techniques, as shown in Table 1 below:

TABLE I. CATEGORIZING TECHNIQUES [9]

\begin{tabular}{|c|c|}
\hline Interval(\%) & Category \\
\hline $0-20$ & Very low \\
\hline $21-40$ & Low \\
\hline $41-60$ & Medium \\
\hline $61-80$ & High \\
\hline $81-100$ & Very high \\
\hline
\end{tabular}

\section{RESUlt AND Discussion}

Before you begin to format your paper, first write and save the content as a separate text file. Complete all content and organizational editing before formatting. Please note sections A-D below for more information on proofreading, spelling and grammar.

Keep your text and graphic files separate until after the text has been formatted and styled. Do not use hard tabs, and limit use of hard returns to only one return at the end of a paragraph. Do not add any kind of pagination anywhere in the paper. Do not number text heads-the template will do that for you.

\section{A. Results}

The presentation of the results in this study is based on 3 aspects of knowledge that are used as a reference in obtaining a description of teacher competence, namely pedagogic competence, and professional competence. A total of 16 indicators were used in measuring teacher pedagogical competencies, namely TK2, TK3, PK1, PK2, PK3, PK4, PK5, TPK1, TPK2, TPK3, TPK4, PCK1, PCK2, PCK3, TPCK1, and TPCK5. Meanwhile, professional competence consists of 14 indicators namely TK1, TK4, CK1, CK2, CK3, CK4, TCK1, TCK2, TCK3, TCK4, PCK4, TPCK2, TPCK3, and TPCK4. The results obtained in this study will be described in the following.

\section{1) Pedagogic competence}

The analysis of the physics teacher's pedagogic competency is reviewed from 3 aspects of knowledge, namely pedagogic knowledge consisting of 8 indicators, technological knowledge consisting of 2 indicators, and collaboration of pedagogic and technological knowledge consisting of 6 indicators. Furthermore, it is these indicators which then represent every aspect of knowledge in measuring the level of pedagogical competency possessed by the teacher. Based on the results of data analysis using simple statistics the total score of each statement item is obtained as shown in Table 2. 


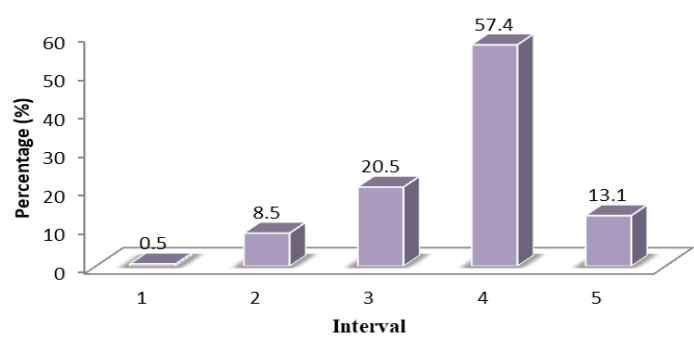

Fig. 1. Percentage score of pedagogic competence

From the above data, a description of the distribution of pedagogical competencies is obtained by a physics teacher in the Merauke District. As many as $57.35 \%$ of physics teachers choose the answer sufficient can. The data can be seen in Figure 1 above.

TABLE II. THE SCORE OF EACH PEDAGOGIC COMPETENCE INDICATOR

\begin{tabular}{|c|c|c|c|c|c|c|c|c|c|c|c|c|c|}
\hline \multirow{2}{*}{$\begin{array}{l}\text { No. } \\
\text { item }\end{array}$} & \multirow{2}{*}{ Label } & \multicolumn{5}{|c|}{ Percentage of score earned $(\%)$} & \multirow{2}{*}{$\begin{array}{l}\text { No. } \\
\text { item }\end{array}$} & \multirow{2}{*}{ Label } & \multicolumn{5}{|c|}{ Percentage of score earned $(\%)$} \\
\hline & & 1 & 2 & 3 & 4 & 5 & & & 1 & 2 & 3 & 4 & 5 \\
\hline 2 & TK2 & 0 & 18.2 & 27.3 & 36.3 & 18.2 & 15 & TPK2 & 0 & 9.1 & 36.4 & 45.4 & 9.1 \\
\hline 3 & TK3 & 9.1 & 0 & 18.2 & 45.4 & 27.3 & 16 & TPK3 & 0 & 9.1 & 36.4 & 45.4 & 9.1 \\
\hline 5 & PK1 & 0 & 9.1 & 18.2 & 63.6 & 9.1 & 17 & TPK4 & 0 & 9.1 & 18.2 & 72.7 & 0 \\
\hline 6 & PK2 & 0 & 9.1 & 0 & 81.8 & 9.1 & 22 & PCK1 & 0 & 0 & 9.1 & 45.4 & 45.5 \\
\hline 7 & PK3 & 0 & 9.1 & 9.1 & 72.7 & 9.1 & 23 & PCK2 & 0 & 9.1 & 9.1 & 45.4 & 36.4 \\
\hline 8 & PK4 & 0 & 9.1 & 36.4 & 54.5 & 0 & 24 & PCK3 & 0 & 9.1 & 27.3 & 45.4 & 18.2 \\
\hline 9 & PK5 & 0 & 9.1 & 27.3 & 54.5 & 9.1 & 26 & TPCK1 & 0 & 9.1 & 27.3 & 54.5 & 9.1 \\
\hline 14 & TPK1 & 0 & 9.1 & 18.2 & 72.7 & 0 & 30 & TPCK5 & 0 & 9.1 & 9.1 & 81.8 & 0 \\
\hline
\end{tabular}

TABLE III. THE SCORE OF EACH PROFESSIONAL COMPETENCE INDICATOR

\begin{tabular}{|c|c|c|c|c|c|c|c|c|c|c|c|c|c|}
\hline \multirow{2}{*}{$\begin{array}{l}\text { No. } \\
\text { item }\end{array}$} & \multirow{2}{*}{ Label } & \multicolumn{5}{|c|}{ Percentage of score earned $(\%)$} & \multirow{2}{*}{$\begin{array}{l}\text { No. } \\
\text { item }\end{array}$} & \multirow{2}{*}{ Label } & \multicolumn{5}{|c|}{ Percentage of score earned $(\%)$} \\
\hline & & 1 & 2 & 3 & 4 & 5 & & & 1 & 2 & 3 & 4 & 5 \\
\hline 1 & TK1 & 18.2 & 9 & 36.4 & 36.4 & 0 & 19 & TCK2 & 0 & 9.1 & 27.3 & 63.6 & 0 \\
\hline 4 & TK4 & 0 & 0 & 45.4 & 36.4 & 18.2 & 20 & TCK3 & 9 & 0 & 18.2 & 45.5 & 27.3 \\
\hline 10 & CK1 & 0 & 9 & 45.5 & 45.5 & 0 & 21 & TCK4 & 0 & 0 & 45.4 & 36.4 & 18.2 \\
\hline 11 & CK2 & 0 & 9 & 45.5 & 45.5 & 0 & 25 & PCK4 & 0 & 9.1 & 9.1 & 72.7 & 9.1 \\
\hline 12 & CK3 & 0 & 9 & 54.6 & 36.4 & 0 & 27 & TPCK2 & 0 & 9.1 & 27.3 & 63.6 & 0 \\
\hline 13 & CK4 & 0 & 9.1 & 0 & 81.8 & 9.1 & 28 & TPCK3 & 0 & 9.1 & 27.3 & 54.5 & 9.1 \\
\hline 18 & TCK1 & 0 & 9.1 & 27.3 & 63.6 & 0 & 29 & TPCK4 & 0 & 9.1 & 18.2 & 63.6 & 9.1 \\
\hline
\end{tabular}

Furthermore, the data above is presented into 5 interval classes based on the Riduan and Akdon's categorization techniques. The frequency distribution shows that the distribution of pedagogical competencies of teachers is still in the very low, low and medium categories. This data also provides an illustration that in general physics teachers who teach in Merauke District have a moderate ability to master learning methods and strategies in class. This is of course influenced by many factors. Therefore, based on the results of data analysis, it will be explained in the discussion section on various factors that cause the pedagogical competence of teachers who have not been able to reach the high category. The frequency distribution that shows the pedagogical competency category of physics teachers teaching in the Merauke District can be seen Figure 2 below. 


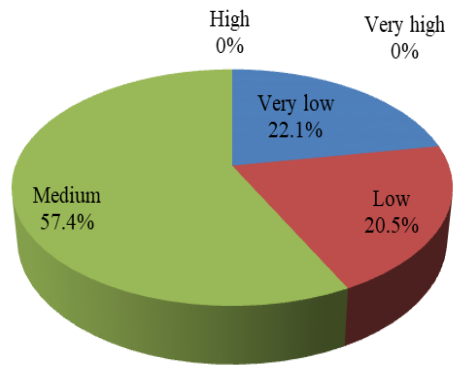

Fig. 2. Pedagogic competence of physics teachers

\section{2) Professional competence}

The analysis of teacher professional competence in this research is based on 3 aspects of knowledge namely content knowledge, technology knowledge and knowledge about the integration of technology into learning content. Each of these aspects is built by several indicators to be aware of data collection in the field. Content knowledge consists of 5 indicators, technology knowledge consists of 2 indicators and collaborative knowledge between technology and content consists of 7 indicators. Based on the results of data analysis using simple statistics the total score of each statement item is obtained as shown in Table 3 above.

Based on the data above obtained an overview of the distribution of professional competence of physics in Merauke District. As many as $53.25 \%$ of physics teachers choose the answer sufficient can as shown in Figure 3 below.

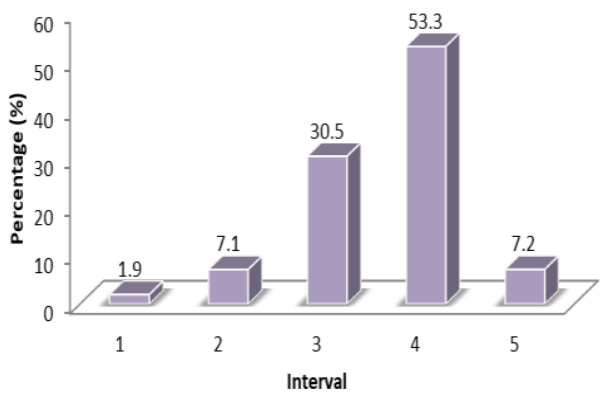

Fig. 3. Percentage score of professional competence

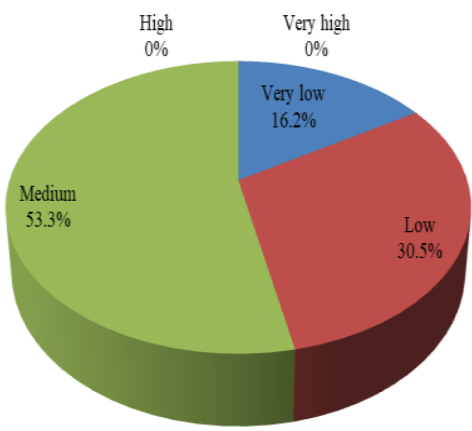

Fig. 4. Professional competence of physics teachers

\section{B. Discussion}

Teacher's pedagogic competency is seen from pedagogic knowledge and technological knowledge and collaboration between the two knowledge. Based on the data in Table 2 it can be seen that the pedagogical knowledge component shows that $81.8 \%$ of physics teachers can plan group activities for students even though only and $72.7 \%$ of physics teachers have been able to identify the right topic for group activities and $63.6 \%$ of physics teachers already know how to guide students to learn independently. These results also illustrate that the teacher already has a good ability in designing and implementing physics learning in the classroom and can develop the potential of students by training to learn independently. This result is also supported by the data that can be seen in Table 2 that there are $45.4 \%$ of physics teachers who can design learning and $36.4 \%$ are very able. In line with this Supriyadi et al in his research revealed that a teacher's pedagogical competence is reflected in how to plan and implement learning by choosing the right models, methods and strategies in teaching material [10]. Furthermore, the ability of teachers to evaluate student learning outcomes is in the category of able and very able with a percentage of $45.5 \%$ each, but for aspects of the ability to create and develop a curriculum and syllabus of physics there are only $45.5 \%$ of teachers who are in the category of able and $18.2 \%$ in the category of very able.

Futhermore, the technology knowledge component consists of TK2 and TK3 indicators. As many as $45.4 \%$ of physics teachers stated that they could learn technology easily, but only $36.4 \%$ of physics teachers had the technical ability to use technology. These results also illustrate that the ability of teachers to use each technology is relatively low. This is reinforced by data on collaboration between pedagogic knowledge and technology knowledge where the percentage of teachers in the category can use technology for classroom learning activities is only $45.4 \%$. Though the aspect of the ability to use technology in learning is the most important thing in improving teacher's pedagogical competence. The use of technology in learning can be in the form of interactive learning media to attract learners' interests and prepare online learning facilities for students to be able to provide access and ease of learning for example by using websites or similar platforms. What is clear in this study is that most teachers are still at the stage of thinking to choose the appropriate strategies and approaches in implementing technology-based learning so that the use of technology is only used limitedly for discussion purposes in social media forums such as in the WhatsApp or Facebook groups. Overall analysis results show that the competence of physics teachers in Merauke District teaching at the secondary school level is still in the medium category with a percentage of $57.4 \%$ as shown in Figure 2. This is due to only a small proportion of teacher's physics subjects that can integrate pedagogic knowledge and technological knowledge so that learning cannot take place effectively and efficiently.

As for professional competence in terms of content knowledge and technological knowledge as well as a combination of content and technology knowledge. Base on the results shown in Table 3 it can be explained that as many as $81.8 \%$ of teachers already have extensive knowledge about physics learning materials but teachers still find it difficult to find methods and strategies to improve students' understanding of the material being taught. This is indicated 
by the percentage of teachers in the category of CK1 and CK2 that is only $45.4 \%$. Therefore, the professional competence of an educator is reflected in the understanding of the material, structure, concepts, and principles taught to stimulate students to learn actively and dynamically. Judging from the technological knowledge can be explained that the percentage of teachers who can use conference software such as WhatsApp and also teachers who can teach using websites is only $36.4 \%$. This also means that the use of the internet as a source of teacher information in obtaining learning material is still very limited because the ability to use technology is still relatively low.

The use of computers and LCD projectors in the learning process has begun to be done by teachers, namely $45.4 \%$ of teachers apply it so that from some teachers also sometimes provide simulations through computers to represent the content of physics learning materials. In addition, teachers have also been able to choose materials according to basic learning competencies that can be collaborated with the use of technology, but teachers are still constrained by the limitations of facilities and also the ability of teachers to use technology to facilitate learners is still minimal. From the analysis data it is known that overall the distribution of professional competence of physics teachers in Merauke District at the secondary school level is in the medium category with a percentage of $53.3 \%$. This result is influenced by the low ability of physics teachers in integrating technology into learning materials. Integration of technology into learning materials related to the ability of teachers to package learning materials becomes more interesting and interactive with the help of technology such as making learning materials in power point equipped with animations related to the material to be delivered besides the teacher can also make learning videos that contain concepts physics whose objects are easy to find in everyday life so that learning in class can run effectively, efficiently and conducive and most importantly is to make it easy for teachers to transfer knowledge to students and vice versa students easier and faster to understand the contents and concepts of the material delivered by the teacher.

\section{CONCLUSION}

Based on the results of data analysis and discussion, it can be concluded that pedagogical competence and professional competence of physics teachers were in the medium category. The results of this study indicate that physics teachers who teach in Merauke District have not been able to carry out physics learning based on information and communication technology.

\section{ACKNOWLEDGMENT}

We thank Musamus University for facilities, supports, and publications.

\section{REFERENCES}

11] Pemerintah Republik Indonesia, Undang-Undang Republik Indonesia Nomor 14 Tahun 2005 Tentang Guru Dan Dosen. Republik Indonesia, 2005.

[2] A. Reski, R. F. Nikat, and D. K. Sari, "Analysis of the lecture's teaching skills using structural equation modeling method," in IOP Conference Series: Earth and Environmental Science, 2019, vol. 343, no. 1, pp. 1-6. DOI: https://doi.org/10.1088/1755-

\section{$1315 / 343 / 1 / 012238$.}

Pemerintah Republik Indonesia, Peraturan Pemerintah Nomor 19 Tahun 2005 tentang Standar Nasional Pendidikan, 2005.

[4] D. A. Schmidt, E. Baran, A. D. Thompson, P. Mishra, M. J. Koehler, and T. S. Shin, "Technological pedagogical content knowledge (Track): The development and validation of an assessment instrument for preservice teachers," J. Res. Technol. Educ., vol. 42, no. 2, pp. 123-149, 2009. DOI: https://doi.org/10.1080/15391523.2009.10782544

[5] L. S. Shulman, "Those Who Understand: Knowledge Growth in Teaching," Educ. Res., vol. 15, no. 2, 1986, pp. 4-14. DOI: https:// doi.org/ 10.2307/1175860.

[6] M. J. Koehler, M. Punya, and K. Kristen, The Technological Pedagogical Content Knowledge Framework. New York: Springer Science, 2014, pp. 101-111. DOI: https:// doi.org/ 10.1007/978-1-4614-3185-5 9.

[7] A. Reski, A. Henukh, and M. Simbolon, "Profile Technological Pedagogical Content Knowledge (TPACK) Prospective Teacher of PPL Participants," in 2nd International Conference on Social Science (ICSS 2019), 2019, vol. 383, pp. 113-115. DOI: https://doi.org/10.2991/icss-19.2019.207.

[8] Riduwan, Skala Pengukuran Variable-variabel Penelitian. Bandung: Alfabeta, 2011.

[9] Riduan and Akdon, Rumus dan Data dalam Analisis Statistik. Bnadung: Alfabeta, 2008.

[10] S. Supriyadi, S. Bahri, and R. S. Waremra, "Kemampuan Technological Pedagogical Content Knowledge (TPACK) Mahasiswa Pada Matakuliah Strategi Belajar Mengajar Fisika," J. Inspirasi Pendidik., 2018, vol. 8, no. 2, pp. 1-9. DOI: https://doi.org/10.21067/jip.v8i2.2632 . 